International Research Journal of Engineering, IT \& Scientific Research
Available online at https://sloap.org/journals/index.php/irjeis/
Vol. 5 No. 4, July 2019, pages: 1 7
ISSN: 2454-2261
https://doi.org/10.21744/irjeis.v5n4.647

\title{
Linking Society: Higher Education Institution Role in Local Development
}

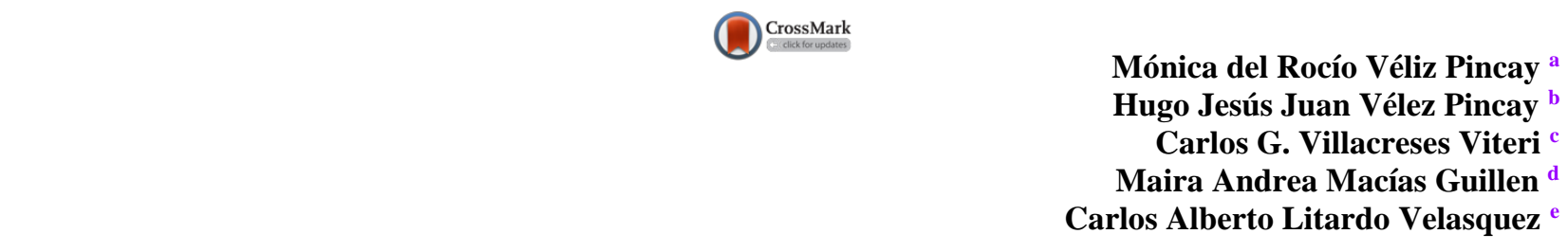

Article history:

Received: 27 March 2019

Accepted: 31 May 2019

Published: 7 June 2019

\section{Keywords:}

industry;

local development;

substantive functions;

teaching learning;

university;

\begin{abstract}
The University now is the managing three substantive core functions: teaching, research, and links, all go hand in the teaching-learning process, the interesting thing about this idea is that the Higher Education Center becomes the main axis of knowledge. The objective of this research is to know the way that Higher Education Institutions have raised their incidence in local development. Deepening, from the studies conducted in the processes of linkage, which is where the relationship with their teaching activities has established of research and where quality preparation has given to the students, allowing them to satisfy the requirements of the productive matrix of the province. The career of Industrial Engineering has taken for the study because this is the fundamental pillar in supporting the change of productive matrix of the province. From the knowledge of the agro-economic values that can contribute to local development and as a result of this research it has been determined that they have affected the territory surrounding the Institution in projects that enhance local development, shown in its actions in the Municipal Gad of Portoviejo.
\end{abstract}

2454-2261 ${ }^{\circledR}$ Copyright 2019. The Author. This is an open-access article under the CC BY-SA license (https://creativecommons.org/licenses/by-sa/4.0/) All rights reserved.

\section{Author correspondence:}

Mónica del Rocío Véliz Pincay,

$\mathrm{MsC}$. Industrial Engineering Career, FCMFQ.

Universidad Técnica de Manabí, Portoviejo, Ecuador.

Email address: mdveliz@utm.edu.ec

\footnotetext{
${ }^{a}$ MsC. Industrial Engineering Career, FCMFQ. Universidad Técnica de Manabí, Portoviejo, Ecuador

${ }^{\mathrm{b}} \mathrm{MsC}$. Teacher Holder. Universidad Técnica de Manabí, Portoviejo, Ecuador

${ }^{c}$ MsC. Civil Engineer, Dean of FCMFQ, Universidad Técnica de Manabí, Portoviejo, Ecuador

${ }^{\mathrm{d}}$ Ing. Electrical engineering career, FCMFQ. Universidad Técnica de Manabí, Portoviejo, Ecuador

${ }^{\mathrm{e}} \mathrm{MsC}$. Industrial Engineering Career, FCMFQ. Universidad Técnica de Manabí, Portoviejo, Ecuador
} 


\section{Introduction}

Universities have an important role in the development of contemporary society and they have had it since its emergence as Higher Education Centers, these being nourished by young people living in the environment from the territory where their academic activities are carried out, they can investigate from the local levels, which are the most relevant issues affecting local and territorial development (Núñez \& AA, 2016).

The Pan American Health Organization (PAHO) has analyzed how the University should adapt its response to programs that facilitate the linkage of the University with local territorial planning, competition of Decentralized Autonomous Governments, as well as the participation of students and professors in practical actions of intervention, technical cooperation and research, converging with the various efforts to improve the quality of life and contribute to integral local development (PAHO, 2012). This analysis was done through an exchange of experiences carried out by the Governments and Local Organizations and the University Academic Units.

In this meeting the need for the insertion of the University in the improvement of the quality of life of the Ecuadorian population through linking processes was assessed, where students can know what the needs and difficulties of the population are but seen from the locality.

As stated by Pico (2015), the Industrial Engineer is aimed at finding solutions to the various problems in the industrial field by the demands of the consumer market and the different needs of different industries such as metallurgical, construction, mechanical, oil, automotive, mining, textile, agricultural, food among others.

The Industrial Engineering career of the Escuela Politécnica del Litoral (ESPOL) was designed to meet the needs of the productive sector (public and private), which seeks to guide its operations towards the increase of productivity and quality, to compete successfully within of the local and international business environment, due to the need for engineers that are specifically related to the use of human, technical, material, economic, financial and information resources, where future engineers come out trained as professionals with a solid academic preparation capable of make competitive in the sector the company or small SMEs, so that the Industrial Engineer has the ability to design, manage and control; production systems, logistics, quality, safety and occupational health and human resources management; as well as applying operations research for process optimization (ESPOL, 2016); This is learned in the universities where they come from, associating the linking projects with the teaching practices.

As stated by Brito et al., (2016), in Ecuador, Higher Education Institutions include as an end the link with society as a mission of public and private universities, these functions before 2010 did not respond to a structured program with defined objectives, they used to lack rigorous consideration within university regulations.

The province of Manabí has a high potential of the agro-industry, the Industrial Engineering career must be a pioneer in the training and preparation of the new generations, where through the linking projects can study the existing problems and define the models to follow prioritizing food production, since these are of interest in the province and thus enhance local development from strategies that have been drawn at the national level (Ruiz, 2016; Pemayun \& Maheswari, 2017), always prevailing knowledge in agricultural production, allowing them to through the research carried out, develop projects that serve as self-supply, creating compensation for the less advantaged producers for the development of the agro-industry (Perez et al., 2017; Gamez et al., 2017).

Another aspect related to the substantive processes of the University, is the model where the research that is developed creates a teacher-student interrelation and that really allows to design new knowledge from the teaching process that enhances the career curriculum, where the research helps to perfect the teaching-learning process guided by the teacher where it is based on two fundamental pillars: environmental sustainability and territorial development (UTM, 2017).

According to the Institutional Research Plan of the Technical University of Manabí UTM, in its environment there is a nascent manufacturing industry (Research, 2018), derived from the agricultural, fishing and forestry productions of the province, this shows that there are sources for the development of the link in the area, according to the linking program, the cantons with influences in the University are mainly: Portoviejo, Chone, Sucre and Santa Ana (UTM, 2017).

Thus we can say that in Chone, several projects related to the agroindustry have been developed, one of them, the Malanga Chifle factory, this topic was developed in a research project, where they showed that the biggest negative impact that occurs to the environment, is the generation of solid waste, domestic and wastewater, which can be minimized by applying environmental mitigation measures (Cedeño, 2016). As it can be stated, these types of impact can be studied in linking processes, so that they can invent and propose the best solutions through local studies in connection projects. Currently the canton Chone needs Industrial Engineers, prepared from the undergraduate who can meet the expectations of the development of small industry in such a way that local development is enhanced. 


\section{Materials and Methods}

To stop the study a bibliographic review was made to know the actions that today are developed as substantive activities in the Universities of the region, the database of the linking projects that were developed in the career of Industrial Engineering in the last three was taken. years, in addition to carrying out a qualitative analysis of the projects carried out and the area where the students performed their relationship

\section{Results and Discussions}

The career of Industrial Engineering, of the Universidad Técnica de Manabí (UTM), has as its mission, to train engineers recognized at the national level for their leadership, solid technological scientific knowledge and humanistic values, based on up-to-date curriculum according to the demands of the labor environment and entrepreneurship opportunities, developing lines of scientific and technological research linked to the progress of the country (FCMFQ, 2016).

Although within the framework of their mission they do not have local development incorporated as a mission, when their content is analyzed it is noted, as the preparation of scientific leaders in the area of entrepreneurship is reflected, this task is reflected in the projects of linkage developed in the last three years, some of these link work have been presented at scientific events (Litardo et al., 2010).

As shown in figure 1, the number of linkage projects developed since 2016 and the number of students involved to date. It can also be seen that the trend line in relation to the number of projects has decreased, in the case of the students involved has been increasing, taking into account that we are not yet in the middle of 2019 this parameter should continue to rise.

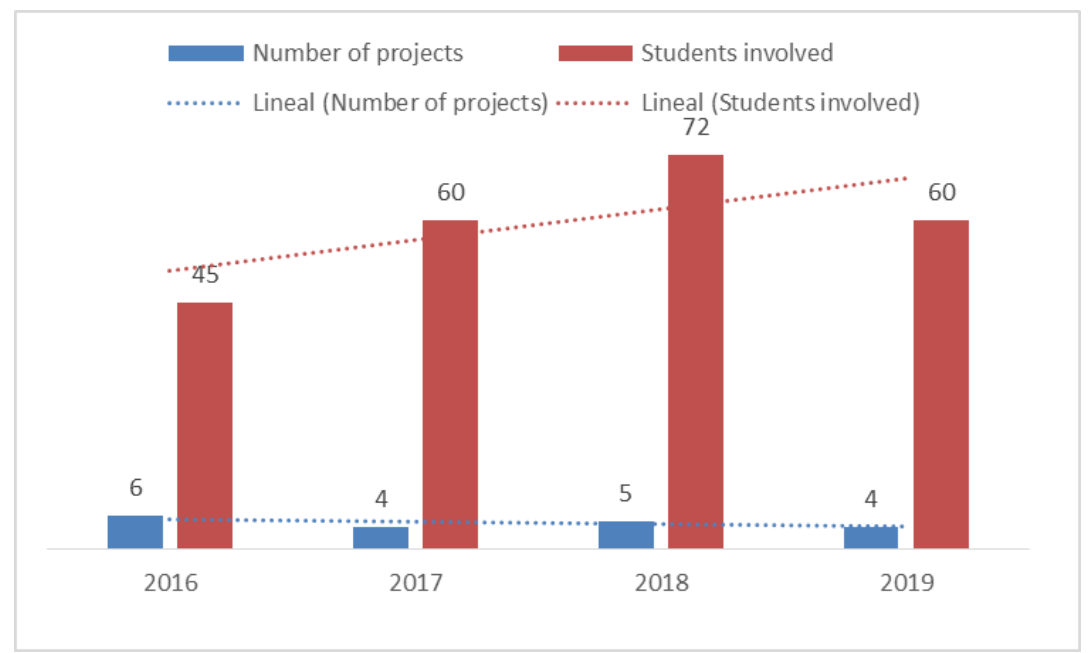

Figure 1. Linking projects developed 2016-2019 and involved students

From the linking projects developed, different social and economic objectives were benefited, in figure 2 we can see a graph that shows the type of beneficiary entities.

Pincay, M. del R. V., Pincay, H. J. J. V., Viteri, C. G. V., Guillen, M. A. M., \& Velasquez, C. A. L. (2019). Linking society: Higher education institution role in local development. International Research Journal of Engineering, IT \& Scientific Research, 5(4), 1-7. https://doi.org/10.21744/irjeis.v5n4.647 


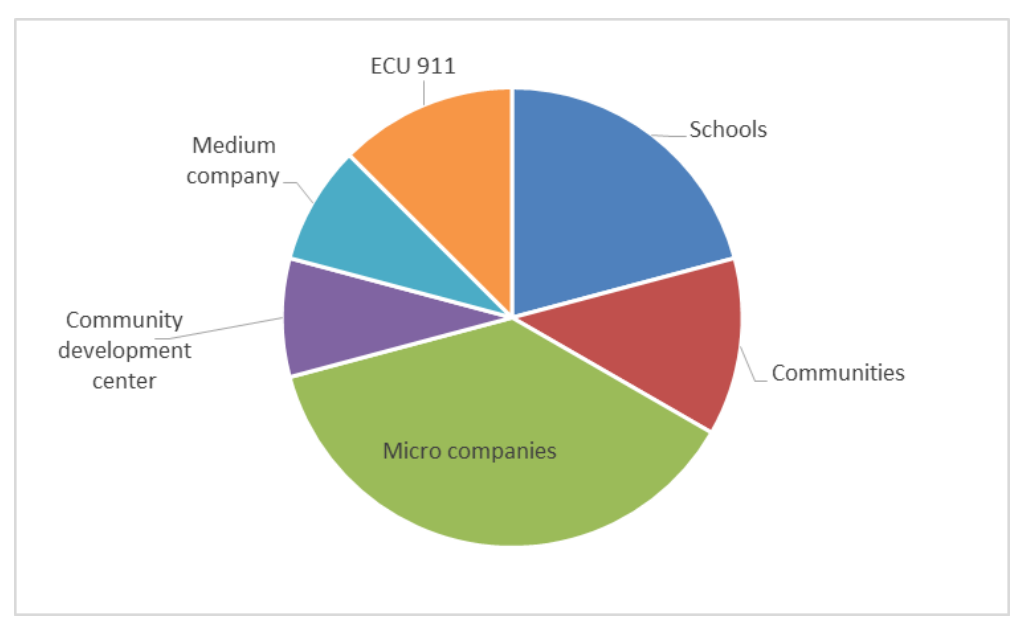

Figure 2. Beneficiary economic and social objectives

As can be seen, microenterprises and schools have been the entities that have benefited the most, some with training projects, preparation of manuals, procedures for the preparation of cleaning products in communities and others in projects linked to safety plans, occupational health and the preparation of emergency plans for possible undesired events.

Significant is the link with companies to assess the psychosocial risk factors in the well-being and health status of workers in ASOPROPAVA micro-fishing enterprise.

In the study, several cantons and parishes were involved, among them of special interest where the University has incidence, being of special interest the link made in the Florón of the Andrés de Vera parish of the Portoviejo canton, on topics such as good practices of manufacturing, for the production of cleaning products; Fishing communities were also involved in this substantive task of the house of study.

Of the 19 linking projects developed, 18 projects were in the Portoviejo canton and one in the city of Manta, all of them with an impact on the local development of the Municipality, head of the province of Manabí, where the University plays its main role corroborating the raised by Brito et al., (2016), that the University responds and develops in a territorial scenario where the society is characterized by its complexity, uncertainty, chaos, systemic emergency and synergistic interaction between internal actors to the educational institution and external to the territorial subjects. In this dynamic, three key actors emerge teachers, students, and the community; trilogy from which, there are planning processes oriented to the link with society, research and individual and corporate learning.

In this research, the participation of 7 teachers of the Industrial Engineering career as tutors of the bonding process was achieved, in figure 3 the total number of teachers involved is observed.

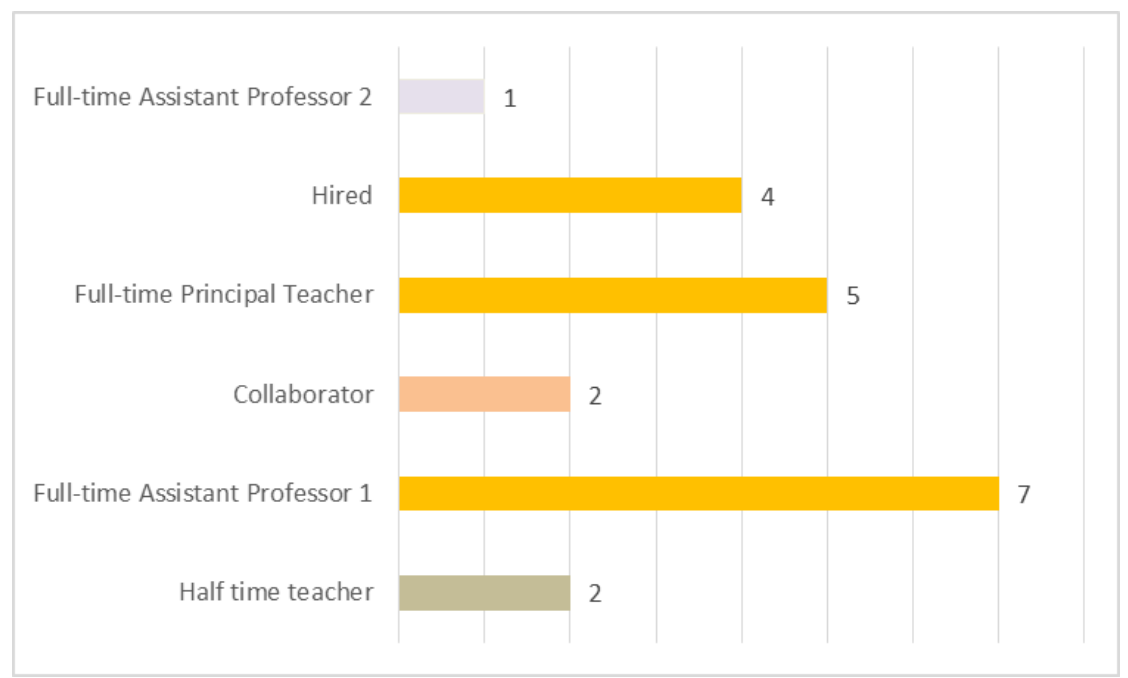

Figure 3. The total number of teachers involved is observed 
As can be seen, the largest incidental teachers are in the full-time assistant professors 1 categories, followed by the full-time professors and the contracted professors, as it is obvious that the greatest incidents are those with the highest incidence. that dominate the career template.

\section{Conclusion}

The Institutions of Higher Education are the pillar of empowerment of local development, proven through the preparation of their students to face a quality social process, being able to develop strategies for the improvement of socioeconomic conditions in their territorial environment. The career of Industrial Engineering has teachers able to instruct and guide their students in the processes of linkage, in the incidents problems in local development.

Conflict of interest statement and funding sources

The author(s) declared that they have no competing interest.

Statement of authorship

The author(s) have a responsibility for the conception and design of the study. The author(s) have approved the final article.

Acknowledgments

Special recognition is given to the management of the university, for supporting the linkage activity and for allowing the development of the projects in different localities, promoting the substantive basic activity in the acculturation process in the community environment.

Pincay, M. del R. V., Pincay, H. J. J. V., Viteri, C. G. V., Guillen, M. A. M., \& Velasquez, C. A. L. (2019). Linking society: Higher education institution role in local development. International Research Journal of Engineering, IT \& Scientific Research, 5(4), 1-7. https://doi.org/10.21744/irjeis.v5n4.647 


\section{References}

Brito Gaona, LF, Gordillo Quizphe, I., \& Quezada Abad, CJ (2016). The link with society and the public university in Ecuador. Contributions to Social Sciences Magazine .

Cedeño, DC, Sentí, Ve, \& Rodriguez, JPF (2016). Case base for the cataloging of open educational resources. DYNA New Technologies, 3 (1).

ESPOL. (2016). Industrial engineer. SPAM Repository, http://www.fimcp.espol.edu.ec/es/pregrado/industrial_engineering

FCMFQ. (2016). Historical review. https://www.utm.edu.ec/fcm/index.php/nosotros

Gamez, MR, Perez, AV, Sera, AS, \& Ronquillo, ZM (2017). Renewable energy sources and local development. International Journal of Social Sciences and Humanities, $1(2)$, 1019. https://doi.org/10.29332/ijssh.v1n2.31

Litardo, C., Morales, RA, \& Ponce, CG (2010). Study of psychosocial risks in work environments of the zonal coordination 4 ECU 911, Portoviejo. Memories of the II International Scientific Convention of the UTM, https://utm.edu.ec/convencion2018/

Monserrate Ruiz-Cedeño, S. (2016). The Agrifood Sector and its competitiveness based on associative models / The agrifood sector and its competitiveness from associative models. Industrial Engineering , 37 (3), 323-332.

Núñez, J. \& AA (2016). University and local development: Latin American contributions. https://www.oei.es/historico/cienciayuniversidad/spip.php?article6539

PAHO (2012). The university education and its contribution to the local development process. https://www.paho.org/ecu/index.php?option=com_content\&view=article\&id=592:1a-formacion-universitariaaporte-proceso-desarrollo-local\&Itemid=360

Pemayun, A. G. P., \& Maheswari, A. I. A. (2017). Economic impacts of craftsman statue on community based tourism development. International Journal of Social Sciences and Humanities, 1(3), 59-73. https://doi.org/10.29332/ijssh.v1n3.56

Perez, A. V., Gamez, M. R., Viteri, C. G. V., \& Quiroz, A. M. V. (2017). Community power as a driving force for sustainable local development. International Research Journal of Engineering, IT \& Scientific Research, 3(4), 819.

Pico, C. A. (2015). Curriculum redesign and its impact on the quality of the training of professionals of the School of Industrial Engineering of the Faculty of Mathematical, Physical and Chemical Sciences of the Technical University of Manabí. Repository Technical University of Manabí, http://repositorio.utm.edu.ec/bitstream/123456789/181/1/rediseno\%20curricular.pdf

Research, I. d. (2018). Institutional Research Plan. https://www.utm.edu.ec/investigacion/images/documentos/reglasy-codigo/Plan-de-Investigacion-version-abril-12-2018.pdf

UTM. (2017). Bonding plan 2017-2018. https://www.utm.edu.ec/.../images/.../Plan-de-Investigacion-version-abril12-2018.pdf 


\section{Biography of Authors}

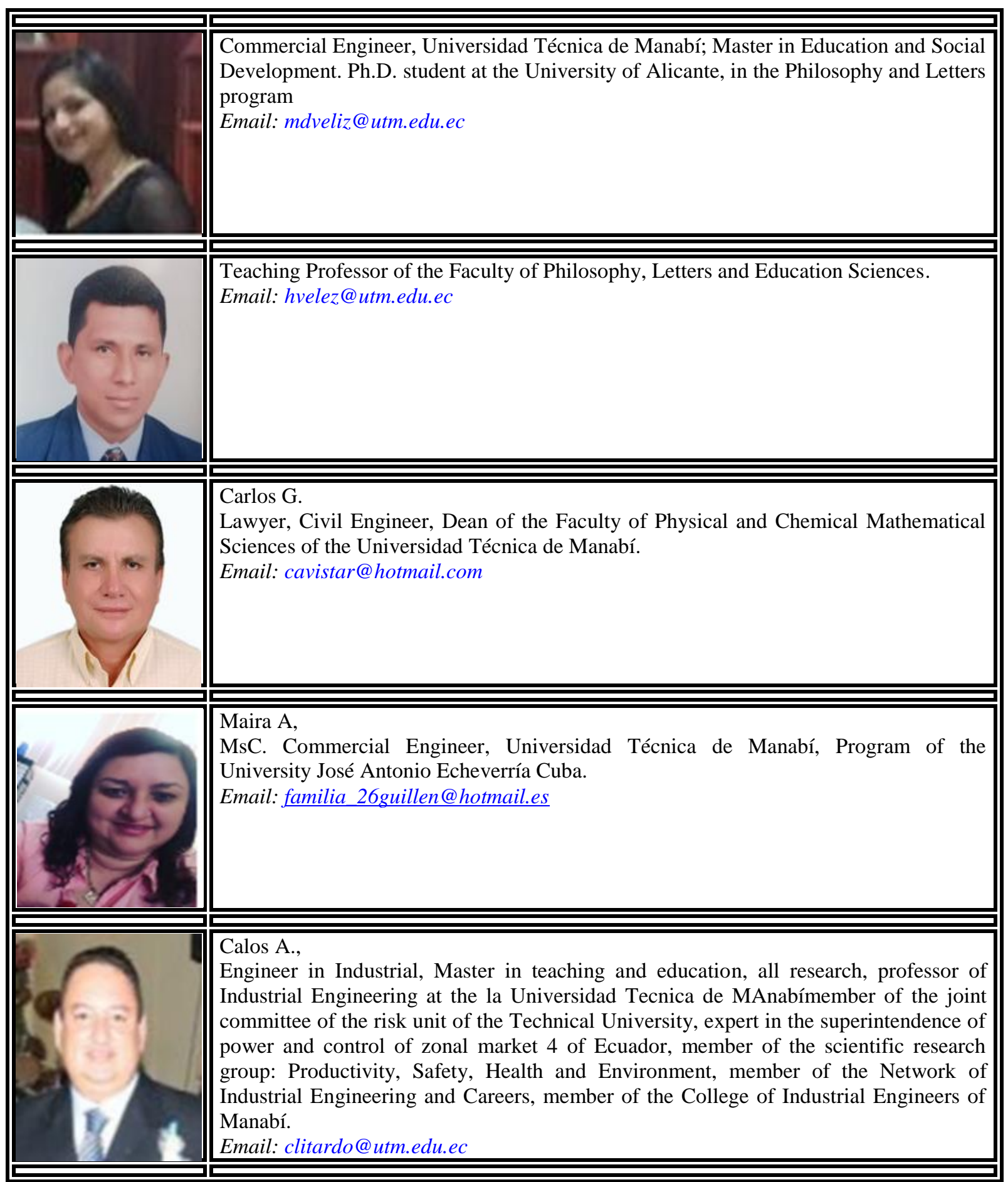

Pincay, M. del R. V., Pincay, H. J. J. V., Viteri, C. G. V., Guillen, M. A. M., \& Velasquez, C. A. L. (2019). Linking society: Higher education institution role in local development. International Research Journal of Engineering, IT \& Scientific Research, 5(4), 1-7. https://doi.org/10.21744/irjeis.v5n4.647 